\title{
The Role of Androgen Hormones in Early Follicular Development
}

\section{Catiele Garcia Gervásio, Marcelo Picinin Bernuci, Marcos Felipe Silva-de-Sá, and Ana Carolina Japur de Sá Rosa-e-Silva}

\author{
Sector of Human Reproduction, Department of Gynecology \& Obstetrics, Ribeirão Preto Medical School, \\ University of São Paulo, Avenida Bandeirantes, 3900 Ribeirão Preto, SP, Brazil
}

Correspondence should be addressed to Ana Carolina Japur de Sá Rosa-e-Silva; anasars@fmrp.usp.br

Received 19 December 2013; Accepted 18 February 2014; Published 10 April 2014

Academic Editors: R.-C. Chian, N. A. Ginsberg, S. Palomba, and C. J. Petry

Copyright (C) 2014 Catiele Garcia Gervásio et al. This is an open access article distributed under the Creative Commons Attribution License, which permits unrestricted use, distribution, and reproduction in any medium, provided the original work is properly cited.

\begin{abstract}
Background. Although chronic hyperandrogenism, a typical feature of polycystic ovary syndrome, is often associated with disturbed reproductive performance, androgens have been shown to promote ovarian follicle growth in shorter exposures. Here, we review the main effects of androgens on the regulation of early folliculogenesis and the potential of their application in improving follicular in vitro growth. Review. Androgens may affect folliculogenesis directly via androgen receptors (ARs) or indirectly through aromatization to estrogen. ARs are highly expressed in the granulosa and theca cells of early stage follicles and slightly expressed in mature follicles. Short-term androgen exposure augments FSH receptor expression in the granulosa cells of developing follicles and enhances the FSH-induced cAMP formation necessary for the transcription of genes involved in the control of follicular cell proliferation and differentiation. AR activation also increases insulin-like growth factor (IGF-1) and its receptor gene expression in the granulosa and theca cells of growing follicles and in the oocytes of primordial follicles, thus facilitating IGF-1 actions in both follicular recruitment and subsequent development. Conclusion. During the early and intermediate stages of follicular maturation, locally produced androgens facilitate the transition of follicles from the dormant to the growing pool as well as their further development.
\end{abstract}

\section{Introduction}

The development of ovarian follicles begins during fetal life with the transformation of primordial germ cells into oocytes enclosed in structures called follicles [1,2]. Some of these follicles are recruited to start a long progress of growth and differentiation, during which the proteins required for oocyte maturation are progressively synthesized and accumulated [3, 4]. All events related to follicular development are regulated by appropriate signals originating from the growing oocyte itself and from the somatic cells that surround it $[5,6]$ and also by complex interactions between gonadotropin hormones, sex steroids, and diverse growth factors $[7,8]$.

The sex steroids produced by follicular cells are known to play major roles in the regulation of ovarian function. When present in the systemic circulation, these steroids actively participate in the regulation of pituitary gonadotropin secretion, and when present in the ovarian microenvironment, they act as important paracrine factors for the maintenance of follicular development [9]. Although much of the information about the role of sex steroids in ovarian functioning has been obtained in studies directed at the action of estrogens [1012] and progestogens [13-15], increasing attention is being devoted to the action of androgen hormones because the activation of the androgen receptor located in follicular cells $[16,17]$ modulates the expression and activity of important genes for the maintenance of ovarian follicle development [17-19].

Additional evidence of the action of androgens in the regulation of folliculogenesis has arisen from in vitro studies showing that various androgens, including testosterone, androstenedione, and dihydrotestosterone, can stimulate the growth and development of ovarian follicles in mammals [20-22]. The reduction of reproductive function and 


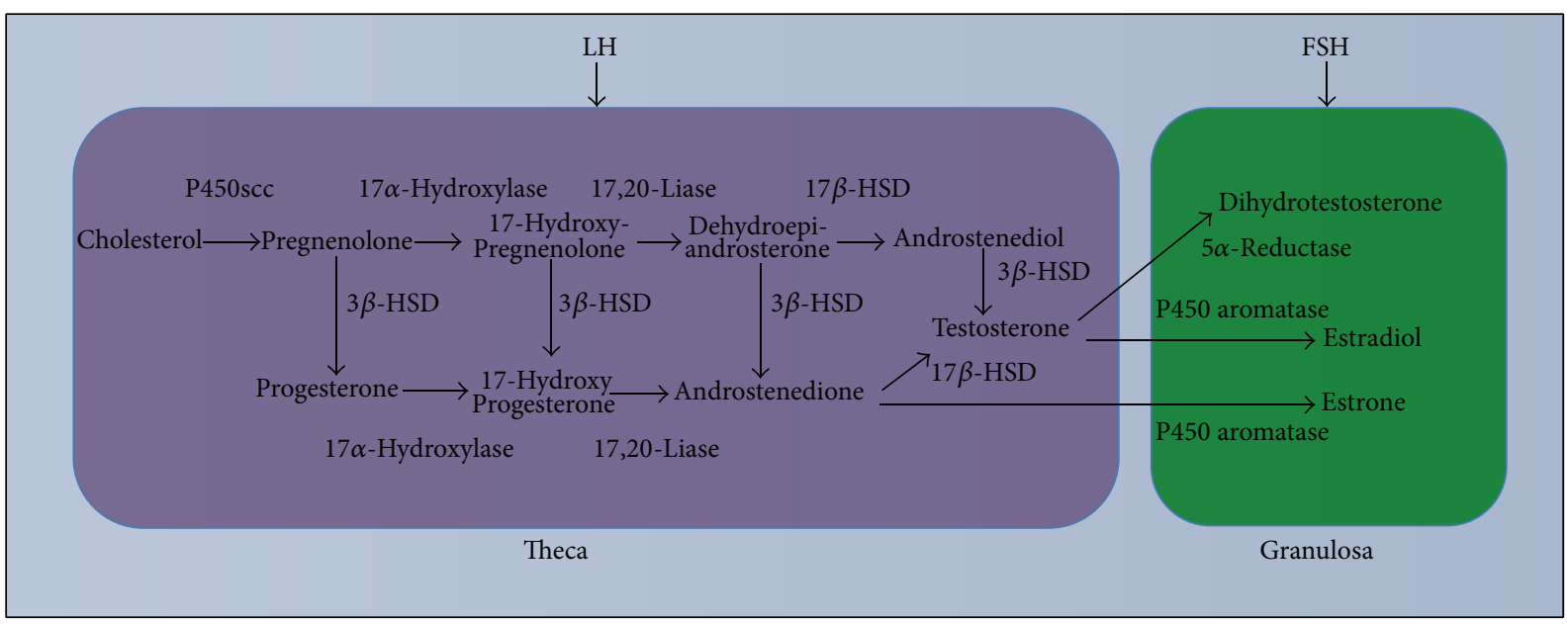

FIGURE 1: Schematic view of the production of androgen hormones by ovarian follicular cells according to the two-cells-two-hormones model. In the theca cells, the androgens (androstenedione and testosterone) are produced in response to the luteinizing hormone (LH) stimulus. After diffusing towards the granulosa cells, the androgens are converted to estrogens (estradiol and estrone) by the enzyme aromatase under the action of the follicle stimulating hormone (FSH). P450scc, enzyme responsible for the cleavage of the lateral chain of cholesterol; $3 \beta$-HSD, $3 \beta$-hydroxysteroid dehydrogenase; $17 \beta$-HSD, $17 \beta$-hydroxysteroid dehydrogenase.

the development of premature ovarian failure in mice with the nonselective deletion of the androgen receptor gene [23$25]$ support the hypothesis of the involvement of androgens in the regulation of follicular development. Reinforcing these findings, mice carrying this deletion show the impaired in vitro development of preantral follicles [26]. Additionally, a more pronounced expression of the androgen receptors has been reported to occur in preantral follicles $[27,28]$, suggesting the major action of androgens during the initial stages of folliculogenesis.

From a clinical point of view, polycystic ovary syndrome (PCOS) is a nosologic entity that affects approximately 5$10 \%$ of women of reproductive age and is characterized by increased ovarian androgen production and chronic anovulation. The excessively androgenic microenvironment of the ovary is believed to have a negative impact on follicular development, which, in addition to LH hypersecretion, promotes follicle stagnation in the early stages of development (initial antral), inhibiting the development of a dominant and ovulatory follicle and leading to chronic anovulation and infertility. Among the various therapeutic alternatives for infertile patients with this diagnosis is the in vitro maturation of follicles obtained from their ovaries without previous induction. The results of this technique are limited in terms of the reproductive outcome, likely due to the impaired quality of the oocytes developed in hyperandrogenic environments [29]. Another therapeutic possibility in these cases is in vitro fertilization procedure, which shows that patients with PCOS, despite a larger number of oocytes, have similar pregnancy rates. This suggests a poorer utilization of the oocytes obtained, again indicating impaired oocyte quality [30].

Therefore, there is evidence in the literature of the participation of androgens in follicular development both as essential adjuvants and as harmful agents when present in excessive amounts. This indicates the relevance of understanding the role of androgens in the regulation of folliculogenesis, as well as the possibility of recreating in vitro conditions capable of guaranteeing the full growth of ovarian follicles to mimic as much as possible the in vivo intrafollicular environment [31]. On this basis, the objective of the current review was to present more relevant data regarding the involvement of androgens in the regulation of folliculogenesis and to provide information for the design of future culture strategies that can be used to promote the in vitro development of ovarian follicles.

\section{Androgen Synthesis in the Ovary}

The androgens androstenedione, testosterone, and dihydrotestosterone are primarily synthesized from cholesterol and are produced by the ovary in a sequential manner together with other sex steroids, progestogens, and estrogens, with each steroid serving as a substrate for the subsequent one in a cascade of events known as steroidogenesis [3234]. The classical two-cells-two-hormones model describes the role of follicular cells (theca and granulose) and of gonadotropins (follicle stimulating hormone (FSH) and luteinizing hormone (LH)) in steroid synthesis and secretion in the ovary, with emphasis on the cooperation of the two cell types that are necessary for androgen production. In general, the androstenedione synthesized from progestogens is converted to testosterone by the action of the enzyme $17 \beta$ hydroxysteroid dehydrogenase in theca cells under the LH stimulus, and the produced androgen is passively transported to the granulose cells where it is converted in estrogen by the action of aromatase under the FSH stimulus [35] (Figure 1).

Due of this conversion of testosterone in estradiol in the granulosa, many of the actions of androgens on the growth 
and differentiation of ovarian follicles can be indirectly mediated by the action of androgens as precursors in the biosynthesis of estrogens. Although the actions of estrogens on the ovary are well known in terms of the pattern of expression and function of estrogen receptors [36], little is known about the direct involvement of androgens in terms of their interaction with the specific receptor in the regulation and maintenance of folliculogenesis.

\section{Expression of the Androgen Receptor in the Ovary}

The cellular actions of androgens require the binding and activation of the specific ligand receptor called the androgen receptor (AR) [37]. Both the protein and messenger RNA of AR have been detected in the ovary of various mammalian species, such as rodents [38,39], cattle [40, 41], sheep [42], swine $[43,44]$, non-human primates $[16,17]$, and humans $[45,46]$. Although most of these studies have indicated that granulosa cells are the predominant sites of AR expression, theca and ovarian stromal cells also express AR [20,47,48]. In oocytes, AR expression exhibits an evolutive profile that is highly expressed in amphibians [49], moderately expressed in rodents [20], little expressed in ruminants [42, 44], and incipient or absent in non-human primates and in humans $[17,50-52]$.

In rodents and primates, $\mathrm{AR}$ expression appears to be regulated along follicular development, being increased in ovaries containing a larger number of preantral and antral follicles of small diameter and reduced in ovaries containing periovulatory follicles $[53,54]$. The analysis of the expression in isolated follicles shows that, in these species, follicles in the early stages of development express a larger number of AR than those in more advanced stages (Table $1, *$ ) [20, 55]. Additionally, a differential gradient of AR expression is noted in mature follicles, which are little expressed in mural granulosa cells and are highly expressed in cumulus cells [56]. The profile of mRNA and the protein of AR in different follicular classes are presented in Table 1.

\section{Mechanisms of Action of the Androgens}

Like all steroid hormones, the androgens primarily exert their functions by binding and activating specific nuclear receptors that trigger the intracellular events responsible for the beginning of the transcription of target genes $[57,58]$. Additionally, the androgens can also exert their effects by interacting with receptors located on the cell membrane to perform rapid, non-genomic actions involved in the activation of various transcription factors [59-61]. Thus, the activated ARs transcriptionally regulate the expression of a selected group of genes via direct or indirect association with the regulatory regions of (enhancer/promoter) upstream elements [37, 62, 63]. Although several autocrine and/or paracrine factors involved in the regulation of the development of ovarian follicles have been described $[6,64,65]$, only some genes responsible for the transcription of these factors have been tested as AR targets. Particularly important among them are the genes related to FSH receptors, insulin-like growth factor-1 (IGF-1), and aromatase enzyme [18, 19, 66, 67]. The main findings regarding the direct action of androgen hormones on the in vivo and in vitro control of follicular development in mammals are based on the transcriptional actions of AR in follicular cells. As reported for AR expression in the oocytes, the physiological role of androgens in oocyte maturation appears to have been lost over evolution, being phylogenetically replaced by the action of gonadotropins [68].

\section{Role of Androgens in Early Follicular Development}

5.1. In Vivo Effects. Although the effects of chronic exposure to high androgen concentrations during the prenatal or postnatal period in different mammalian species are extensively known and are correlated with irregularities of the reproductive cycle and changes in the ovarian morphology in patients with a diagnosis of PCOS [69], few studies have been designed to assess the effects of short-term exposure to low androgen concentrations. The main results obtained in studies evaluating the effects of the in vivo administration of androgen hormones on early follicular development in different species are listed in Table 2 and described below.

Subcutaneous implants for the controlled release of low androgen doses have been used as an efficient tool for the study of the effects of short-term androgen exposure using experimental animal models. In non-human primates, subcutaneous implants containing different doses of testosterone promoted an expressive increase in follicular recruitment, growth, and survival [70]. These effects appear to be mediated by a local amplification of the action of both IGF-1 and FSH because exposure to testosterone induced an increase in IGF-1, IGF-1 receptor, and FSH receptor mRNA in the ovaries of these animals $[18,19,66]$. The increase of follicular recruitment was positively correlated with increases in IGF1 and IGF-1 receptor mRNA in the oocytes of primordial follicles, suggesting an indirect action of androgens via the IGF-1 system on follicular activation [19]. All of the effects on both ovarian morphology and the IGF-1 and FSH system induced via exposure to testosterone were fully replicated when subcutaneous implants containing the nonaromatizable androgen dihydrotestosterone were used, showing that the effects of androgens are mediated by AR and not by conversion to estrogens. Similarly, the in vitro treatment of granulosa cells obtained from the antral follicles of swine with dihydrotestosterone increases the action of IGF-1 as a stimulus to cell proliferation, as well as the effect of growth and differentiation factor 9 (GDF9) in the presence of IGF$1[71,72]$, both of which are effects that are blocked by the presence of the AR antagonist hydroxyflutamide. The positive correlation between the expression of the AR gene and the proliferation of granulosa cells and follicular growth further supports the hypothesis of the involvement of androgens in follicular growth via AR [17] (Figure 2).

In other mammalian species, short-term exposure to low androgen doses was also related to increased follicular 


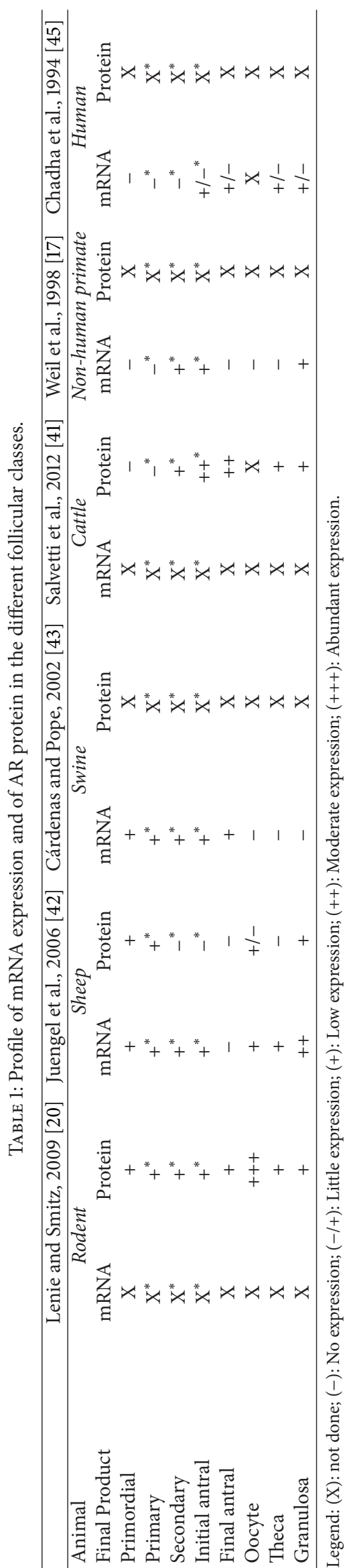


TABLE 2: Effects of the in vivo administration of androgen hormones on early follicular development.

\begin{tabular}{|c|c|c|c|}
\hline Animal & Methodology used & Main results & Reference \\
\hline \multirow{4}{*}{$\begin{array}{l}\text { Non-human } \\
\text { primate }\end{array}$} & $\begin{array}{l}\text { Subcutaneous implants containing testosterone } \\
(4 \mathrm{mg} / \mathrm{kg} \text { animal weight } / \text { day }) \text { for } 3 \text { days, }(400 \mu \mathrm{g} / \mathrm{kg} \\
\text { animal weight/day) for } 10 \text { days, }(20 \mathrm{~g} / \mathrm{kg} \text { animal } \\
\text { weight } / \text { day }) \text { for } 5 \text { days, or dihydrotestosterone } \\
(145 \mu \mathrm{g} / \mathrm{kg} \text { animal weight/day) for } 5 \text { days. }\end{array}$ & $\begin{array}{l}\text { Increased follicular retrieval, growth, and } \\
\text { survival. Increased theca and granulosa } \\
\text { cell proliferation. }\end{array}$ & $\begin{array}{c}\text { Vendola et al., } \\
1998 \text { [70] }\end{array}$ \\
\hline & $\begin{array}{l}\text { Subcutaneous implants containing testosterone } \\
(20 \mu \mathrm{g} / \mathrm{kg} \text { animal weight/day) or dihydrotestosterone } \\
(145 \mu \mathrm{g} / \mathrm{kg} \text { animal weight/day) for } 5 \text { days. }\end{array}$ & $\begin{array}{l}\text { Increased expression of mRNA for IGF-I } \\
\text { and for IGF-I receptor in granulosa and } \\
\text { theca cells of growing follicles. }\end{array}$ & $\begin{array}{c}\text { Vendola et al., } \\
1999 \text { [18] }\end{array}$ \\
\hline & $\begin{array}{l}\text { Subcutaneous implants containing testosterone } \\
(20 \mu \mathrm{g} / \mathrm{kg} \text { animal weight/day) or dihydrotestosterone } \\
(145 \mu \mathrm{g} / \mathrm{kg} \text { animal weight/day) for } 5 \text { days; testosterone } \\
(400 \mu \mathrm{g} / \mathrm{kg} \text { animal weight/day) for } 3 \text { or } 10 \text { days. }\end{array}$ & $\begin{array}{l}\text { Increased follicular retrieval and } \\
\text { expression of IGF-I mRNA and of IGF-I } \\
\text { receptor in oocytes of primordial follicles. }\end{array}$ & $\begin{array}{c}\text { Vendola et al., } \\
1999 \text { [19] }\end{array}$ \\
\hline & $\begin{array}{l}\text { Subcutaneous implants containing testosterone } \\
(4 \mathrm{mg} / \mathrm{kg} \text { animal weight/day) for } 3 \text { days or testosterone } \\
(0.4 \mathrm{mg} / \mathrm{kg} \text { animal weight/day) for } 10 \text { days. }\end{array}$ & $\begin{array}{l}\text { Increased expression of FSH receptor } \\
\text { mRNA in granulosa cells of growing } \\
\text { follicles. }\end{array}$ & $\begin{array}{l}\text { Weil et al., } \\
1999 \text { [66] }\end{array}$ \\
\hline Swine & $\begin{array}{l}\text { Intramuscular administration of dihydrotestosterone } \\
\text { ( } 60 \mu \mathrm{g} / \mathrm{kg} \text { animal weight) for the first } 3 \text { days of the early } \\
\text { follicular phase or for the last } 3 \text { days of the late follicular } \\
\text { phase; dihydrotestosterone ( } 6 \mu \mathrm{g} / \mathrm{kg} \text { animal weight) } \\
\text { administered from the 13th day of the estrous cycle to } \\
\text { the next estrus. }\end{array}$ & $\begin{array}{l}\text { Increased ovulatory rate and increased } \\
\text { expression of FSH receptor mRNA in } \\
\text { periovulatory follicles. }\end{array}$ & $\begin{array}{l}\text { Cárdenas et al., } \\
2002[73]\end{array}$ \\
\hline Rodent & $\begin{array}{l}\text { Administration of a subcutaneous implant containing } \\
\text { dihydrotestosterone }(83 \mu \mathrm{g} / \mathrm{kg} \text { animal weight/day) for } \\
90 \text { days. }\end{array}$ & $\begin{array}{l}\text { Increased follicular retrieval in preantral } \\
\text { follicles. Increased potential for in vitro } \\
\text { development of preantral follicles. }\end{array}$ & $\begin{array}{l}\text { Xue et al., } \\
2012 \text { [74] }\end{array}$ \\
\hline
\end{tabular}
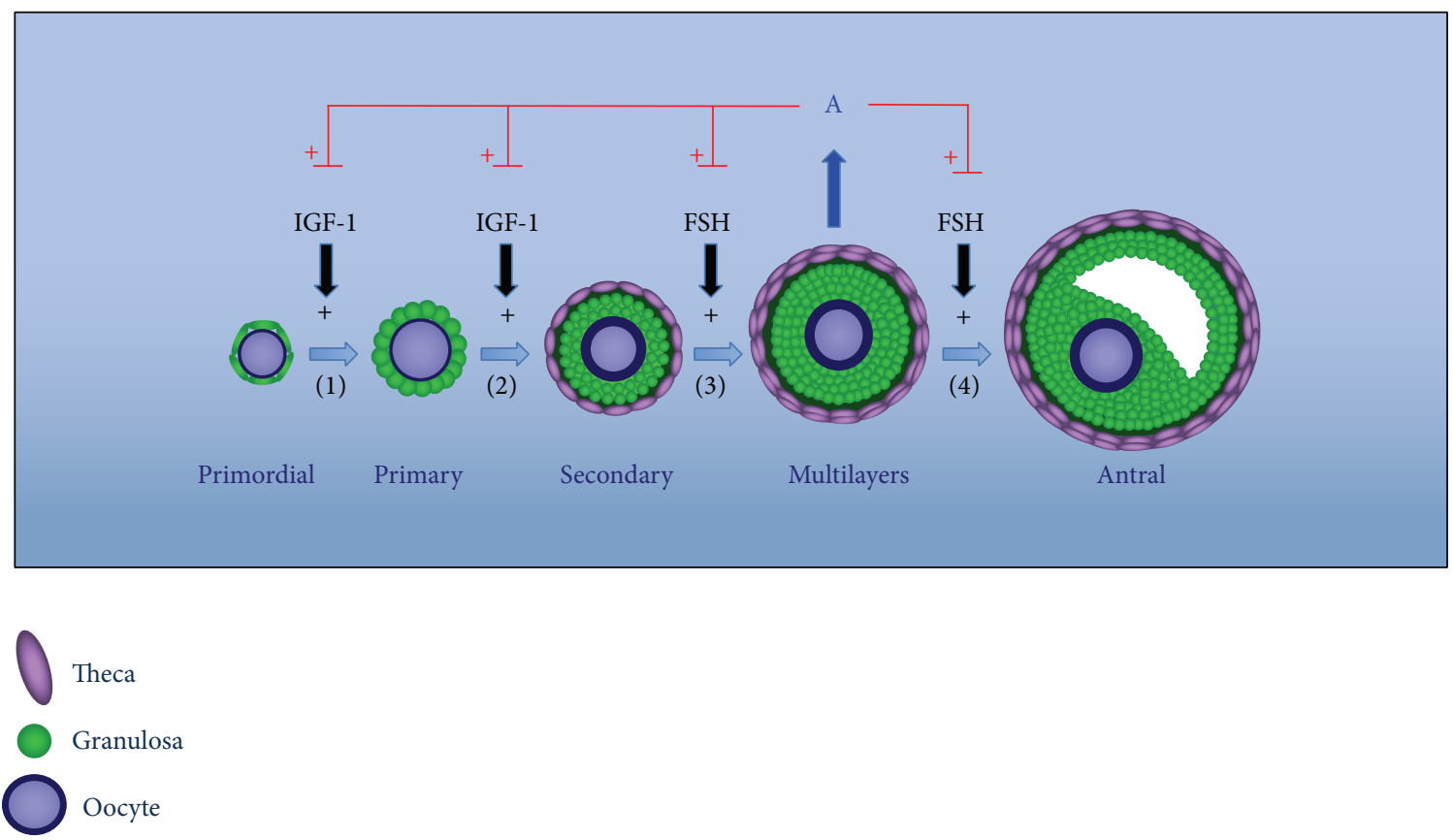

FIGURE 2: Schematic presentation of the action of androgen hormones on early follicular development. The androgens produced by the growing follicles can promote the transition from (1) primordial to primary follicles and (2) from primary to secondary follicles through the amplification of the actions of the IGF-1 system and can also amplify the actions of follicle stimulating hormone (FSH) on the promotion of the subsequent growth of (3) preantral and (4) antral follicles. 
TABLE 3: Reproductive results after the in vitro maturation in nonstimulated cycles of patients with polycystic ovary syndrome.

\begin{tabular}{lcccc}
\hline & Maturation (\%) $(N)$ & Fertilization $(\%)(N)$ & Cleavage $(\%)(N)$ & Pregnancy $(\%)(N)$ \\
\hline Zhao et al., 2006 [78] & $73.7 \%(632 / 857)$ & $75.3 \%(476 / 632)$ & $91.2 \%(434 / 476)$ & $40 \%(19 / 47)$ \\
Cha et al., 2000 [75] & $62.2 \%(708 / 1.139)$ & $68 \%(481 / 708)$ & $88.1 \%(266 / 302)$ & $27.1 \%(85 / 23)$ \\
Holzer et al., 2007 [77] & $68.3 \%(104 / 154)$ & $73.3 \%(71 / 104)$ & $81.4 \%(62 / 71)$ & $50 \%(6 / 12)$ \\
Zhao et al., 2009 [79] & $68.8 \%(1.753 / 2.548)$ & $70.28 \%(1.232 / 1.753)$ & $90.2 \%(1.111 / 1.232)$ & $40 \%(56 / 140)$ \\
Bos-Mikich et al. 2011 [80] & $63 \%(350 / 556)$ & $62 \%(218 / 350)$ & $95 \%(208 / 218)$ & $32 \%(11 / 34)$ \\
\hline
\end{tabular}

recruitment and growth. In swine, the intramuscular administration of dihydrotestosterone during the first 3 days of the early follicular phase and during the last 3 days of the late follicular phase of the reproductive cycle significantly increased the ovulatory rate of these animals [73]. The administration of $10 \mathrm{x}$ diluted doses administered from the 13th day of the estrous cycle to the next estrus promoted a significant increase of mRNA expression of the FSH receptor in periovulatory follicles, suggesting that the increased ovulatory response detected in androgenized animals is in fact related to the increased sensitivity of ovarian follicles to the gonadotropic action induced by the androgen. In rodents, the administration of subcutaneous implants containing dihydrotestosterone promoted the increased expression of FSH receptor mRNA in preantral follicles [74]. Additionally, the potential for the in vitro development of preantral follicles isolated from the ovaries of androgenized animals was superior to that of nonandrogenized follicles, showing that in this species the androgens also promote follicular growth via increased gonadotropic sensitization.

Taken together, these findings suggest that the in vivo action of androgens via AR may regulate both the expression and the action of one or more of the ovarian growth factors necessary for the regulation of follicular recruitment and growth. It should be noted that no in vivo studies have been conducted on the human species because of the limitation represented by the side effects that this practice could cause in women exposed to systemic androgens. A satisfactory model for these evaluations in humans is represented by the study of oocytes obtained from patients with PCOS.

In 1991, Cha et al. [75] reported the first pregnancy resulting from in vitro maturation (IVM); in 1994, Trounson [76] first reported a successful pregnancy process using oocytes aspirated from nonstimulated patients with PCOS. Since then, various studies have performed IVM without stimulation in patients with PCOS with the objective of obtaining pregnancy rates similar to those of fertile women $[75,77-79]$ and to assess the efficacy of IVM and fertilization in nonstimulated patients.

In the studies cited above, immature oocytes were aspirated from infertile patients between days 6 and 14 of the cycle with the aid of transvaginal ultrasound, and those of normal morphology were placed in culture for 24-48 hours; only those with extrusion of the first polar body were submitted to intracytoplasmic sperm injection (ICSI), and transfer was performed 2 to 3 days after ICSI [75, 77-79]. In the cited reports, fertilization rates ranged from $62 \%$ to $75.3 \%$, and cleavage rates ranged from $81.4 \%$ to $95 \%$, which are in agreement with data reported by Trounson et al. [76]. The pregnancy rates reported by Zhao et al. [78] (40\%), Holzer et al. [77] (50\%), and Zhao et al. [79] (40\%) are similar to those of patients with unknown causes of infertility, although Cha et al. [75] and Bos-Mikich et al. [80] reported lower pregnancy rates in PCOS patients $(27.1 \%$ and $32 \%$, resp.). According to Zhao et al. [79], ovarian stimulation is unnecessary; they obtained pregnancy rates similar to those of patients with stimulated cycles (40\%). A similar result was obtained by $\mathrm{Ge}$ et al. [81], who showed that the addition of hCG does not contribute to oocyte maturation. The advantages of nonstimulation are many and include the prevention of ovary hyperstimulation syndrome induced by gonadotropin use, reduction of costs, shorter and continuous treatment cycles, and the prevention of a series of other longterm complications such as hormone-dependent neoplasias [75, 79] (Table 3).

According to Das et al. [82], the anti-Mullerian hormone $(\mathrm{AMH})$ plays a role in PCOS because its values are increased in affected patients compared with control ovulatory women ( $466 \mathrm{ng} / \mathrm{mL}$ and $78 \mathrm{ng} / \mathrm{mL}$, resp., $p=11$ and 8 , resp.). It was also observed that early antral and preantral follicles express $\mathrm{AMH}$, which is absent in primordial and in atresic follicles [82]. These authors speculated about the influence of high androgen levels on the elevation of $\mathrm{AMH}$ values in patients with PCOS.

The relationship between GDF9 and bone morphogenetic protein (BMP15) factor has been studied in the oocytes and granulosa cells of patients with PCOS because these factors play a crucial role in follicle development, ovulation, oocyte maturation, and embryo development. It has been reported that GDF9 and BMP15 are not expressed in patients with PCOS, with a consequent later impairment of cytoplasm maturation and poor oocyte quality, whereas they are expressed in normal ovulatory women $[83,84]$.

5.2. In Vitro Effects. The development of in vitro culture systems able to guarantee the growth and differentiation of isolated ovarian follicles represents a valuable tool for the study of the direct effects of androgens on folliculogenesis. Various in vitro systems have been employed for the culture of preantral follicles in various mammalian species, such as cattle [85], goats [86], non-human primates [66], and humans [87]. However, the production of healthy offspring from oocytes of preantral follicles matured in vitro has been reported only in mice thus far [88]. The main results obtained in studies aiming to evaluate the in vitro effects of androgens 
TABLE 4: Effects of the in vitro administration of androgen hormones on early follicular development.

\begin{tabular}{|c|c|c|c|}
\hline Animal & Methodology used & Main results & Reference \\
\hline Cattle & $\begin{array}{l}\text { Culture of ovarian cortex fragments for } 10 \text { days in } \\
\text { the presence of (i) } 10^{-10} \text { to } 10^{-7} \mathrm{M} \text { testosterone, (ii) } \\
10^{-7} \mathrm{M} \text { estradiol, and (iii) testosterone in } \\
\text { combination with flutamide (AR antagonist). }\end{array}$ & $\begin{array}{l}\text { Testosterone }\left(10^{-7} \text { and } 10^{-6} \mathrm{M}\right) \text { promoted an } \\
\text { increased transition from primary to secondary } \\
\text { follicles, which was inhibited in the presence of } \\
\text { flutamide and was not replicated in the presence } \\
\text { of estradiol. }\end{array}$ & $\begin{array}{l}\text { Yang and } \\
\text { Fortune, } \\
2006[85]\end{array}$ \\
\hline Human & $\begin{array}{l}\text { Culture of ovarian cortex fragments for } 24 \text { hours } \\
\text { in the presence of FSH in combination with (i) } \\
10^{-10} \text { to } 10^{-7} \mathrm{M} \text { testosterone, (ii) } 10^{-10} \text { to } 10^{-7} \mathrm{M} \\
\text { dihydrotestosterone, (iii) } 10^{-10} \text { to } 10^{-8} \mathrm{M} \text { estradiol, } \\
\text { and (iiii) dihydrotestosterone in combination with } \\
\text { casodex (AR antagonist). }\end{array}$ & $\begin{array}{l}\text { Androgens promoted a reduction of ovarian } \\
\text { tissue apoptosis which was inhibited in the } \\
\text { presence of casodex and was not replicated in the } \\
\text { presence of estradiol. }\end{array}$ & $\begin{array}{l}\text { Otala et al., } \\
2004 \text { [87] }\end{array}$ \\
\hline \multirow{7}{*}{ Rodent } & $\begin{array}{l}\text { Culture of isolated preantral follicles for } 6 \text { days in } \\
\text { the presence of (i) anti-androgen antibody in } \\
\text { combination or not with } 1 \mu \mathrm{g} / \mathrm{mL} \\
\text { androstenedione, (ii) casodex (AR antagonist) in } \\
\text { combination with FSH, and (iii) } 1 \mu \mathrm{g} / \mathrm{mL} \\
\text { dihydroxytestosterone in combination with FSH. }\end{array}$ & $\begin{array}{l}\text { Treatment with an anti-androgen antibody } \\
\text { inhibited follicular growth and differentiation; an } \\
\text { effect that was reversed by the addition of } \\
\text { androstenedione. Treatment with casodex } \\
\text { inhibited the positive effect of FSH on follicular } \\
\text { growth which was reversed by the addition of } \\
\text { dihydroxytestosterone. }\end{array}$ & $\begin{array}{c}\text { Murray et al., } \\
1998[21]\end{array}$ \\
\hline & $\begin{array}{l}\text { Culture of isolated preantral follicles for } 6 \text { days in } \\
\text { the presence of FSH in combination or not with } \\
1 \mu \mathrm{g} / \mathrm{mL} \text { androstenedione. }\end{array}$ & $\begin{array}{l}\text { Treatment with FSH promoted follicular growth } \\
\text { and differentiation which were improved when } \\
\text { FSH was combined with androstenedione. }\end{array}$ & $\begin{array}{l}\text { Spears et al., } \\
1998 \text { [89] }\end{array}$ \\
\hline & $\begin{array}{l}\text { Culture of isolated preantral follicles for } 4 \text { days in } \\
\text { the presence of (i) dihydrotestosterone or } \\
\text { testosterone or dihydroxytestosterone or } \\
\text { dihydroxytestosterone sulfate }\left(10^{-11} \text { to } 10^{-7} \mathrm{M} \text { ) (ii) }\right. \\
\text { in combination or not with hydroxyflutamide (AR } \\
\text { antagonist) or FSH. }\end{array}$ & $\begin{array}{l}\text { Treatment with the different androgens promoted } \\
\text { a dose-dependent follicular growth which was } \\
\text { inhibited by the presence of the AR antagonist. } \\
\text { The combination with FSH improved the effect of } \\
\text { androgens on follicular growth. }\end{array}$ & $\begin{array}{l}\text { Wang et al., } \\
2001[22]\end{array}$ \\
\hline & $\begin{array}{l}\text { Culture of isolated preantral follicles for } 13 \text { days in } \\
\text { the presence of (i) } 50 \mu \mathrm{M} \text { hydroxyflutamide (AR } \\
\text { antagonist) in combination with FSH and (ii) } \\
50 \mu \mathrm{M} \text { bicalutamide (AR antagonist) in } \\
\text { combination with FSH. }\end{array}$ & $\begin{array}{l}\text { Follicular growth, production of inhibiting B, and } \\
\text { steroids and oocyte maturation were impaired by } \\
\text { the addition of both AR antagonists. }\end{array}$ & $\begin{array}{l}\text { Lenie and } \\
\text { Smitz } 2009 \\
\text { [20] }\end{array}$ \\
\hline & $\begin{array}{l}\text { Culture of isolated preantral follicles for } 13 \text { days in } \\
\text { the presence of (i) } 20 \text { or } 200 \mathrm{nM} \text { androstenedione } \\
\text { and (ii) testosterone ( } 20 \text { or } 200 \mathrm{nM} \text { or } 2 \mu \mathrm{M} \text { ) both } \\
\text { in the presence of FSH. }\end{array}$ & $\begin{array}{l}\text { Treatment with both androgens at concentrations } \\
\text { of more than } 200 \mathrm{nM} \text { impaired oocyte maturation. }\end{array}$ & $\begin{array}{l}\text { Romero and } \\
\text { Smitz, } 2010 \\
{[92]}\end{array}$ \\
\hline & $\begin{array}{l}\text { Culture of isolated preantral follicles for } 10 \text { days in } \\
\text { the presence of } 10^{-5} \mathrm{M} \text { androstenedione. }\end{array}$ & $\begin{array}{l}\text { Treatment with androstenedione induced changes } \\
\text { in the morphology of granulosa cells compatible } \\
\text { with luteinization. }\end{array}$ & $\begin{array}{l}\text { Okutsu et al., } \\
2010[90]\end{array}$ \\
\hline & $\begin{array}{l}\text { Culture of isolated preantral follicles for } 12 \text { days in } \\
\text { the presence of androstenedione }\left(10^{-11}, 10^{-9} \text {, }\right. \\
\left.10^{-5} \mathrm{M}\right) \text { in combination with FSH. }\end{array}$ & $\begin{array}{l}\text { Treatment with androstenedione at the dose of } \\
10^{-5} \mathrm{M} \text { promoted follicular growth, whereas } \\
\text { higher doses impaired follicular development. } \\
\text { Treatment with androstenedione impaired oocyte } \\
\text { maturation regardless of the dose used. }\end{array}$ & $\begin{array}{l}\text { Tarumi et al., } \\
2012[91]\end{array}$ \\
\hline
\end{tabular}

on early follicular development in different species are listed in Table 4 and described below.

The in vitro treatment of mouse ovarian follicles with $\mathrm{AR}$ antagonists (hydroxyflutamide and bicalutamide) reduced follicular growth during the preantral phase, as well as the meiotic maturation of the enclosed oocyte [20], suggesting the importance of androgen action in follicle maturation. The inability of preantral follicles to develop in vitro to preovulatory stages in the presence of antiandrogen antibodies [21] supports the hypothesis that the actions mediated by ARs are important for the early stages of follicular growth. In the same study, the addition of the AR antagonist casodex inhibited the positive effect of FSH on follicular growth, which was completely reversed when dihydroxytestosterone was added, revealing a joint action of androgens and FSH on follicular development. Additionally, the increased survival and growth of preantral follicles in the presence of androstenedione [89] represents further evidence of the positive action of androgens on follicular development. In the same study [21], the addition of antiestrogen antibodies and of estradiol receptor antagonists (ICI 182, 780) did not modify the positive effects of androstenedione on follicular growth, confirming 
the direct action of androgens on the development of preantral follicle maintenance.

The supplementation of the culture medium with other androgen hormones, that is, dihydrotestosterone, testosterone, DHEA, and DHEA sulfate, at different concentrations $\left(10^{-11}\right.$ to $\left.10^{-7} \mathrm{M}\right)$ also promoted the growth of preantral follicles in a dose-dependent manner [22]. In this study, the AR antagonist hydroxyflutamide but not the aromatase inhibitor fadrozole hydrochloride inhibited the growth response, indicating that estrogens converted from androgens during culture were not responsible for follicular growth.

Androgen hormones are able to promote follicular growth not only during the culture of isolated follicles but also during in situ culture. The addition of testosterone $\left(10^{-10}\right.$ to $10^{-7} \mathrm{M}$ ) to the culture medium of fragments of ovarian cortex from bovine fetuses increased the transition from primary to secondary follicles in a dose-dependent manner [85]. In the same study, the addition of estradiol did not promote the same effect; also, in the presence of the AR antagonist flutamide, the positive effect of testosterone on follicular development was completely abolished, indicating that the observed effect was due to the direct action of androgens via $\mathrm{AR}$. The addition of androgens $\left(10^{-7}\right.$ to $\left.10^{-10} \mathrm{M}\right)$ to the culture medium of fragments of human ovarian cortex tissue significantly inhibited cell apoptosis [87]. Similarly, the addition of estradiol to the culture medium was unable to reproduce the effect of androgen; this effect was also abolished in the presence of the AR antagonist casodex. These findings suggest a positive effect of androgen hormones on the maintenance of the viability of ovarian tissue during culture, which is exclusively due to a direct androgen action mediated by AR.

In general, the results reported here suggest that, at least under in vitro conditions, androgen hormones can promote the growth of ovarian follicles during early stages of development. As observed in vivo, high androgen doses can also have a negative influence on follicular development under in vitro conditions. The in vitro exposure of mouse preantral follicles to androgen concentrations higher than $10^{-5} \mathrm{M}$ induced the precocious luteinization of granulosa cells [90] and also significantly reduced follicular growth and viability [91]. Additionally, under these conditions, the in vitro estradiol and progesterone secretion by developing mouse follicles is exacerbated and is associated with reduced oocyte quality and abnormal chromosome distribution on the metaphase plate [92].

\section{Conclusion}

In general, the results compiled in the present review indicate that during the early and intermediate stages of follicular maturation, when AR expression is more pronounced, the androgens locally produced by the developing follicles facilitate the transcription of genes involved in the control of follicle transition from the reserve pool to the growth pool and of genes involved in the promotion of subsequent follicle development. Additionally, because androgens increase the activities of FSH, especially those related to cell proliferation and differentiation, the fall in AR expression in mature follicles reduces the action of androgens; this is possibly a critical event during the processes of follicular selection and atresia. Under in vitro conditions, submicromolar androgen doses can have a positive influence on the development of preantral follicles, promoting both survival and growth, especially when combined with the addition of FSH.

\section{Conflict of Interests}

The authors declare that they have no conflict of interests regarding the publication of this paper.

\section{References}

[1] A. N. Hirshfield, "Development of follicles in the mammalian ovary," International Review of Cytology, vol. 124, pp. 43-101, 1991.

[2] E. A. McGee and A. J. W. Hsueh, "Initial and cyclic recruitment of ovarian follicles," Endocrine Reviews, vol. 21, no. 2, pp. 200214, 2000.

[3] R. M. Moor, Y. Dai, C. Lee, and J. Fulka Jr., "Oocyte maturation and embryonic failure," Human Reproduction Update, vol. 4, no. 3, pp. 223-236, 1998.

[4] H. Picton, D. Briggs, and R. Gosden, "The molecular basis of oocyte growth and development," Molecular and Cellular Endocrinology, vol. 145, no. 1-2, pp. 27-37, 1998.

[5] J. J. Eppig, K. Wigglesworth, and F. L. Pendola, "The mammalian oocyte orchestrates the rate of ovarian follicular development," Proceedings of the National Academy of Sciences of the United States of America, vol. 99, no. 5, pp. 2890-2894, 2002.

[6] M. M. Matzuk, K. H. Burns, M. M. Viveiros, and J. J. Eppig, "Intercellular communication in the mammalian ovary: oocytes carry the conversation," Science, vol. 296, no. 5576, pp. 21782180, 2002.

[7] A. Gougeon, "Regulation of ovarian follicular development in primates: facts and hypotheses," Endocrine Reviews, vol. 17, no. 2, pp. 121-155, 1996.

[8] K. P. McNatty, A. E. Fidler, J. L. Juengel et al., "Growth and paracrine factors regulating follicular formation and cellular function," Molecular and Cellular Endocrinology, vol. 163, no. 12, pp. 11-20, 2000.

[9] A. E. Drummond, "The role of steroids in follicular growth," Reproductive Biology and Endocrinology, vol. 4, article 16, 2006.

[10] K. Huynh, G. Jones, G. Thouas, K. L. Britt, E. R. Simpson, and M. E. E. Jones, "Estrogen is not directly required for oocyte developmental competence," Biology of Reproduction, vol. 70, no. 5, pp. 1263-1269, 2004.

[11] J. H. Krege, J. B. Hodgin, J. F. Couse et al., "Generation and reproductive phenotypes of mice lacking estrogen receptor $\beta$," Proceedings of the National Academy of Sciences of the United States of America, vol. 95, no. 26, pp. 15677-15682, 1998.

[12] D. W. Schomberg, J. F. Couse, A. Mukherjee et al., “Targeted disruption of the estrogen receptor- $\alpha$ gene in female mice: characterization of ovarian responses and phenotype in the adult," Endocrinology, vol. 140, no. 6, pp. 2733-2744, 1999.

[13] J. P. Lydon, F. J. de Mayo, C. R. Funk et al., "Mice lacking progesterone receptor exhibit pleiotropic reproductive abnormalities," Genes and Development, vol. 9, no. 18, pp. 2266-2278, 1995. 
[14] R. L. Robker, D. L. Russell, L. L. Espey, J. P. Lydon, B. W. O'Malley, and J. S. Richards, "Progesterone-regulated genes in the ovulation process: ADAMTS-1 and cathepsin L proteases," Proceedings of the National Academy of Sciences of the United States of America, vol. 97, no. 9, pp. 4689-4694, 2000.

[15] R. L. Stouffer, "Progesterone as a mediator of gonadotrophin action in the corpus luteum: beyond steroidogenesis," Human Reproduction Update, vol. 9, no. 2, pp. 99-117, 2003.

[16] S. Hild-Petito, N. B. West, R. M. Brenner, and R. L. Stouffer, "Localization of androgen receptor in the follicle and corpus luteum of the primate ovary during the menstrual cycle," Biology of Reproduction, vol. 44, no. 3, pp. 561-568, 1991.

[17] S. J. Weil, K. Vendola, J. Zhou et al., "Androgen receptor gene expression in the primate ovary: cellular localization, regulation, and functional correlations," Journal of Clinical Endocrinology and Metabolism, vol. 83, no. 7, pp. 2479-2485, 1998.

[18] K. Vendola, J. Zhou, J. Wang, and C. A. Bondy, "Androgens promote insulin-like growth factor-I and insulin-like growth factor-I receptor gene expression in the primate ovary," Human Reproduction, vol. 14, no. 9, pp. 2328-2332, 1999.

[19] K. Vendola, J. Zhou, J. Wang, O. A. Famuyiwa, M. Bievre, and C. A. Bondy, "Androgens promote oocyte insulin-like growth factor I expression and initiation of follicle development in the primate ovary," Biology of Reproduction, vol. 61, no. 2, pp. 353357, 1999.

[20] S. Lenie and J. Smitz, "Functional AR signaling is evident in an in vitro mouse follicle culture bioassay that encompasses most stages of folliculogenesis," Biology of Reproduction, vol. 80, no. 4, pp. 685-695, 2009.

[21] A. A. Murray, R. G. Gosden, V. Allison, and N. Spears, "Effect of androgens on the development of mouse follicles growing in vitro," Journal of Reproduction and Fertility, vol. 113, no. 1, pp. 27-33, 1998.

[22] H. Wang, K. Andoh, H. Hagiwara et al., "Effect of adrenal and ovarian androgens on type 4 follicles unresponsive to FSH in immature mice," Endocrinology, vol. 142, no. 11, pp. 4930-4936, 2001.

[23] Y.-C. Hu, P.-H. Wang, S. Yeh et al., "Subfertility and defective folliculogenesis in female mice lacking androgen receptor," Proceedings of the National Academy of Sciences of the United States of America, vol. 101, no. 31, pp. 11209-11214, 2004.

[24] H. Shiina, T. Matsumoto, T. Sato et al., "Premature ovarian failure in androgen receptor-deficient mice," Proceedings of the National Academy of Sciences of the United States of America, vol. 103, no. 1, pp. 224-229, 2006.

[25] S. Yeh, M.-Y. Tsai, Q. Xu et al., "Generation and characterization of androgen receptor knockout (ARKO) mice: an in vivo model for the study of androgen functions in selective tissues," Proceedings of the National Academy of Sciences of the United States of America, vol. 99, no. 21, pp. 13498-13503, 2002.

[26] A. Sen and S. R. Hammes, "Granulosa cell-specific androgen receptors are critical regulators of ovarian development and function," Molecular Endocrinology, vol. 24, no. 7, pp. 1393-1403, 2010.

[27] S. Rice, H. D. Mason, and S. A. Whitehead, "Phytoestrogens and their low dose combinations inhibit mRNA expression and activity of aromatase in human granulosa-luteal cells," Journal of Steroid Biochemistry and Molecular Biology, vol. 101, no. 4-5, pp. 216-225, 2006.

[28] P. T. K. Saunders, R. M. Sharpe, K. Williams et al., "Differential expression of oestrogen receptor $\alpha$ and $\beta$ proteins in the testes and male reproductive system of human and non-human primates," Molecular Human Reproduction, vol. 7, no. 3, pp. 227236, 2001.

[29] L. Jakubowski, "Genetic aspects of polycystic ovary syndrome," Endokrynologia Polska, vol. 56, no. 3, pp. 285-293, 2005.

[30] A. S. Melo, C. S. Vieira, M. A. Barbieri et al., "High prevalence of polycystic ovary syndrome in women born small for gestational age," Human Reproduction, vol. 25, no. 8, pp. 2124-2131, 2010.

[31] I. Smitz, M. M. Dolmans, J. Donnez et al., "Current achievements and future research directions in ovarian tissue culture, in vitro follicle development and transplantation: implications for fertility preservation," Human Reproduction Update, vol. 16, no. 4, pp. 395-414, 2010.

[32] L. Speroff and M. A. Fritz, "Hormone Biosynthesis, metabolism and mechanism of action," in Clinical Gynecoloogic Endocrinology and Infertility, pp. 25-96, LWW-Lippincott Williams and Wilkins, 7th edition.

[33] W. L. Miller and R. J. Auchus, "The molecular biology, biochemistry, and physiology of human steroidogenesis and its disorders," Endocrine Reviews, vol. 32, no. 1, pp. 81-151, 2011.

[34] R. Palermo, "Differential actions of FSH and LH during folliculogenesis," Reproductive BioMedicine Online, vol. 15, no. 3, article 2811, pp. 326-337, 2007.

[35] S. G. Millier, P. F. Whitelaw, and C. D. Smyth, "Follicular oestrogen synthesis: the "two-cell, two-gonadotrophin" model revisited," Molecular and Cellular Endocrinology, vol. 100, no. 12, pp. 51-54, 1994.

[36] S. C. Hewitt, J. Collins, S. Grissom, B. Deroo, and K. S. Korach, "Global uterine genomics in vivo: microarray evaluation of the estrogen receptor $\alpha$-growth factor cross-talk mechanism," Molecular Endocrinology, vol. 19, no. 3, pp. 657-668, 2005.

[37] E. P. Gelmann, "Molecular biology of the androgen receptor," Journal of Clinical Oncology, vol. 20, no. 13, pp. 3001-3015, 2002.

[38] M. Hirai, S. Hirata, T. Osada, K. Hagihara, and J. Kato, "Androgen receptor mRNA in the rat ovary and uterus," Journal of Steroid Biochemistry and Molecular Biology, vol. 49, no. 1, pp. 1-7, 1994.

[39] J.-A. Tan, D. R. Joseph, V. E. Quarmby et al., “The rat androgen receptor: primary structure, autoregulation of its messenger ribonucleic acid, and immunocytochemical localization of the receptor protein," Molecular Endocrinology, vol. 2, no. 12, pp. 1276-1285, 1988.

[40] J. H. Hampton, M. Manikkam, D. B. Lubahn, M. F. Smith, and H. A. Garverick, "Androgen receptor mRNA expression in the bovine ovary," Domestic Animal Endocrinology, vol. 27, no. 1, pp. 81-88, 2004.

[41] N. R. Salvetti, N. S. Alfaro, M. M. Velázquez et al., "Alteration in localization of steroid hormone receptors and coregulatory proteins in follicles from cows with induced ovarian follicular cysts," Reproduction, vol. 144, no. 6, pp. 723-735, 2012.

[42] J. L. Juengel, D. A. Heath, L. D. Quirke, and K. P. McNatty, "Oestrogen receptor $\alpha$ and $\beta$, androgen receptor and progesterone receptor mRNA and protein localisation within the developing ovary and in small growing follicles of sheep," Reproduction, vol. 131, no. 1, pp. 81-92, 2006.

[43] H. Cárdenas and W. F. Pope, "Androgen receptor and folliclestimulating hormone receptor in the pig ovary during the follicular phase of the estrous cycle," Molecular Reproduction and Development, vol. 62, no. 1, pp. 92-98, 2002.

[44] M. Słomczyñska and Z. Tabarowski, "Localization of androgen receptor and cytochrome $\mathrm{P} 450$ aromatase in the follicle and 
corpus luteum of the porcine ovary," Animal Reproduction Science, vol. 65, no. 1-2, pp. 127-134, 2001.

[45] S. Chadha, T. D. Pache, F. J. M. Huikeshoven, A. O. Brinkmann, and T. H. Van der Kwast, "Androgen receptor expression in human ovarian and uterine tissue of long term androgentreated transsexual women," Human Pathology, vol. 25, no. 11, pp. 1198-1204, 1994.

[46] K. Horie, K. Takakura, K. Imai, S. Liao, and T. Mori, "Immunohistochemical localization of androgen receptor in the human endometrium, decidua, placenta and pathological conditions of the endometrium," Human Reproduction, vol. 7, no. 10, pp. 14611466, 1992.

[47] I. J. McEwan, D. McGuinness, C. W. Hay, R. P. Millar, P. T. K. Saunders, and H. M. Fraser, "Identification of androgen receptor phosphorylation in the primate ovary in vivo," Reproduction, vol. 140, no. 1, pp. 93-104, 2010.

[48] M. Szoltys, M. Słomczyńska, and Z. Tabarowski, "Immunohistochemical localization of androgen receptor in rat oocytes," Folia Histochemica et Cytobiologica, vol. 41, no. 1, pp. 59-64, 2003.

[49] L. B. Lutz, L. M. Cole, M. K. Gupta, K. W. Kwist, R. J. Auchus, and S. R. Hammes, "Evidence that androgens are the primary steroids produced by Xenopus laevis ovaries and may signal through the classical androgen receptor to promote oocyte maturation," Proceedings of the National Academy of Sciences of the United States of America, vol. 98, no. 24, pp. 13728-13733, 2001.

[50] T. Suzuki, H. Sasano, N. Kimura et al., "Immunohistochemical distribution of progesterone, androgen and oestrogen receptors in the human ovary during the menstrual cycle: relationship to expression of steroidogenic enzymes," Human Reproduction, vol. 9, no. 9, pp. 1589-1595, 1994.

[51] K. A. Walters, C. M. Allan, and D. J. Handelsman, "Androgen actions and the ovary," Biology of Reproduction, vol. 78, no. 3, pp. 380-389, 2008.

[52] J. R. Wood, D. A. Dumesic, D. H. Abbott, and J. F. Strauss III, "Molecular abnormalities in oocytes from women with polycystic ovary syndrome revealed by microarray analysis," Journal of Clinical Endocrinology and Metabolism, vol. 92, no. 2, pp. 705-713, 2007.

[53] S. G. Hillier, M. Tetsuka, and H. M. Fraser, "Location and developmental regulation of androgen receptor in primate ovary," Human Reproduction, vol. 12, no. 1, pp. 107-111, 1997.

[54] M. Tetsuka, P. F. Whitelaw, W. J. Bremner, M. R. Millar, C. D. Smyth, and S. G. Hillier, "Developmental regulation of androgen receptor in rat ovary," Journal of Endocrinology, vol. 145, no. 3, pp. 535-543, 1995.

[55] S. Rice, K. Ojha, S. Whitehead, and H. Mason, "Stage-specific expression of androgen receptor, follicle-stimulating hormone receptor, and anti-Müllerian hormone type II receptor in single, isolated, human preantral follicles: relevance to polycystic ovaries," Journal of Clinical Endocrinology and Metabolism, vol. 92, no. 3, pp. 1034-1040, 2007.

[56] M. Szoltys and M. Słomczyńska, "Changes in distribution of androgen receptor during maturation of rat ovarian follicles," Experimental and Clinical Endocrinology and Diabetes, vol. 108, no. 3, pp. 228-234, 2000.

[57] D. J. Mangelsdorf, C. Thummel, M. Beato et al., "The nuclear receptor super-family: the second decade," Cell, vol. 83, no. 6, pp. 835-839, 1995.

[58] M. G. Rosenfeld, V. V. Lunyak, and C. K. Glass, "Sensors and signals: a coactivator/corepressor/epigenetic code for integrating signal-dependent programs of transcriptional response," Genes and Development, vol. 20, no. 11, pp. 1405-1428, 2006.

[59] S. Kousteni, T. Bellido, L. I. Plotkin et al., "Nongenotropic, sex-nonspecific signaling through the estrogen or androgen receptors: dissociation from transcriptional activity," Cell, vol. 104, no. 5, pp. 719-730, 2001.

[60] R. M. Lösel, E. Falkenstein, M. Feuring et al., "Nongenomic steroid action: controversies, questions, and answers," Physiological Reviews, vol. 83, no. 3, pp. 965-1016, 2003.

[61] L. B. Lutz, M. Jamnongjit, W.-H. Yang, D. Jahani, A. Gill, and S. R. Hammes, "Selective modulation of genomic and nongenomic androgen responses by androgen receptor ligands," Molecular Endocrinology, vol. 17, no. 6, pp. 1106-1116, 2003.

[62] C. A. Heinlein and C. Chang, "The roles of androgen receptors and androgen-binding proteins in nongenomic androgen actions," Molecular Endocrinology, vol. 16, no. 10, pp. 2181-2187, 2002.

[63] C. A. Quigley, A. de Bellis, K. B. Marschke, M. K. El-Awady, E. M. Wilson, and F. S. French, "Androgen receptor defects: historical, clinical, and molecular perspectives," Endocrine Reviews, vol. 16, no. 3, pp. 271-321, 1995.

[64] J. J. Eppig, "Oocyte control of ovarian follicular development and function in mammals," Reproduction, vol. 122, no. 6, pp. 829-838, 2001.

[65] F. H. Thomas and B. C. Vanderhyden, "Oocyte-granulosa cell interactions during mouse follicular development: regulation of kit ligand expression and its role in oocyte growth," Reproductive Biology and Endocrinology, vol. 4, article 19, 2006.

[66] S. Weil, K. Vendola, J. Zhou, and C. A. Bondy, "Androgen and follicle-stimulating hormone interactions in primate ovarian follicle development," Journal of Clinical Endocrinology and Metabolism, vol. 84, no. 8, pp. 2951-2956, 1999.

[67] Y.-G. Wu, J. Bennett, D. Talla, and C. Stocco, “Testosterone, not $5 \alpha$-dihydrotestosterone, stimulates LRH-1 leading to FSHindependent expression of Cyp 19 and P450scc in granulosa cells," Molecular Endocrinology, vol. 25, no. 4, pp. 656-668, 2011.

[68] M. Li, H. Schatten, and Q.-Y. Sun, "Androgen receptor's destiny in mammalian oocytes: a new hypothesis," Molecular Human Reproduction, vol. 15, no. 3, pp. 149-154, 2009.

[69] D. H. Abbott, D. K. Barnett, C. M. Bruns, and D. A. Dumesic, "Androgen excess fetal programming of female reproduction: a developmental aetiology for polycystic ovary syndrome?" Human Reproduction Update, vol. 11, no. 4, pp. 357-374, 2005.

[70] K. A. Vendola, J. Zhou, O. O. Adesanya, S. J. Weil, and C. A. Bondy, "Androgens stimulate early stages of follicular growth in the primate ovary," Journal of Clinical Investigation, vol. 101, no. 12, pp. 2622-2629, 1998.

[71] T. E. Hickey, D. L. Marrocco, F. Amato et al., "Androgens augment the mitogenic effects of oocyte-secreted factors and growth differentiation factor 9 on porcine granulosa cells," Biology of Reproduction, vol. 73, no. 4, pp. 825-832, 2005.

[72] T. E. Hickey, D. L. Marrocco, R. B. Gilchrist, R. J. Norman, and D. T. Armstrong, "Interactions between androgen and growth factors in granulosa cell subtypes of porcine antral follicles," Biology of Reproduction, vol. 71, no. 1, pp. 45-52, 2004.

[73] H. Cárdenas, J. R. Herrick, and W. F. Pope, "Increased ovulation rate in gilts treated with dihydrotestosterone," Reproduction, vol. 123, no. 4, pp. 527-533, 2002.

[74] K. Xue, J. Y. Liu, B. D. Murphy, and B. K. Tsang, "Orphan nuclear receptor NR4A1 is a negative regulator of DHT-induced rat 
preantral follicular growth," Molecular Endocrinology, vol. 26, no. 12, pp. 2004-2015, 2012.

[75] K. Y. Cha, S. Y. Han, H. M. Chung et al., "Pregnancies and deliveries after in vitro maturation culture followed by in vitro fertilization and embryo transfer without stimulation in women with polycystic ovary syndrome," Fertility and Sterility, vol. 73, no. 5, pp. 978-983, 2000.

[76] A. Trounson, C. Wood, and A. Kausche, "in vitro maturation and the fertilization and developmental competence of oocytes recovered from untreated polycystic ovarian patients," Fertility and Sterility, vol. 62, no. 2, pp. 353-362, 1994.

[77] H. Holzer, E. Scharf, R.-C. Chian, E. Demirtas, W. Buckett, and S. L. Tan, "in vitro maturation of oocytes collected from unstimulated ovaries for oocyte donation," Fertility and Sterility, vol. 88, no. 1, pp. 62-67, 2007.

[78] J.-Z. Zhao, H.-S. Ge, B.-L. Ye et al., "in vitro maturation and fertilization of unstimulated immature oocyte for the treatment of infertile women," Zhonghua Fu Chan Ke Za Zhi, vol. 41, no. 3, pp. 173-176, 2006.

[79] J.-Z. Zhao, W. Zhou, W. Zhang, H.-S. Ge, X.-F. Huang, and J.J. Lin, "in vitro maturation and fertilization of oocytes from unstimulated ovaries in infertile women with polycystic ovary syndrome," Fertility and Sterility, vol. 91, no. 6, pp. 2568-2571, 2009.

[80] A. Bos-Mikich, M. Ferreira, M. Höher et al., "Fertilization outcome, embryo development and birth after unstimulated IVM," Journal of Assisted Reproduction and Genetics, vol. 28, no. 2, pp. 107-110, 2011.

[81] H.-S. Ge, X.-F. Huang, W. Zhang, J.-Z. Zhao, J.-J. Lin, and W. Zhou, "Exposure to human chorionic gonadotropin during in vitro maturation does not improve the maturation rate and developmental potential of immature oocytes from patients with polycystic ovary syndrome," Fertility and Sterility, vol. 89, no. 1, pp. 98-103, 2008.

[82] M. Das, D. J. Gillott, E. Saridogan, and O. Djahanbakhch, "AntiMullerian hormone is increased in follicular fluid from unstimulated ovaries in women with polycystic ovary syndrome," Human Reproduction, vol. 23, no. 9, pp. 2122-2126, 2008.

[83] L. O. T. Resende, A. A. Vireque, L. F. Santana et al., "Singlecell expression analysis of BMP15 and GDF9 in mature oocytes and BMPR2 in cumulus cells of women with polycystic ovary syndrome undergoing controlled ovarian hyperstimulation," Journal of Assisted Reproduction and Genetics, vol. 29, pp. 10571065, 2012.

[84] L. N. Wei, L. L. Li, C. Fang, R. Huang, and X. Y. Liang, "Inhibitory effects of controlled ovarian stimulation on the expression of GDF9 and BMP15 in oocytes from women with PCOS," Journal of Assisted Reproduction and Genetics, vol. 30, no. 10, pp. 1313-1318, 2013.

[85] M. Y. Yang and J. E. Fortune, "Testosterone stimulates the primary to secondary follicle transition in bovine follicles in vitro," Biology of Reproduction, vol. 75, no. 6, pp. 924-932, 2006.

[86] A. B. Duarte, V. R. Araújo, R. N. Chaves et al., "Insulin-like growth factor II, (IGF-II) and follicle stimulating hormone (FSH) combinations can improve the in vitro development of grown oocytes enclosed in caprine preantral follicles," Growth Hormone and IGF Research, vol. 23, no. 1-2, pp. 37-44, 2013.

[87] M. Otala, S. Mäkinen, T. Tuuri et al., "Effects of testosterone, dihydrotestosterone, and $17 \beta$-estradiol on human ovarian tissue survival in culture," Fertility and Sterility, vol. 82, no. 3, pp. 10771085, 2004.
[88] H. H. Motohashi, T. Sankai, and H. Kada, "Live offspring from cryopreserved embryos following in vitro growth, maturation and fertilization of oocytes derived from preantral follicles in mice," Journal of Reproduction and Development, vol. 57, no. 6 , pp. 715-722, 2011.

[89] N. Spears, A. A. Murray, V. Allison, N. I. Boland, and R. G. Gosden, "Role of gonadotrophins and ovarian steroids in the development of mouse follicles in vitro," Journal of Reproduction and Fertility, vol. 113, no. 1, pp. 19-26, 1998.

[90] Y. Okutsu, M. T. Itoh, N. Takahashi, and B. Ishizuka, "Exogenous androstenedione induces formation of follicular cysts and premature luteinization of granulosa cells in the ovary," Fertility and Sterility, vol. 93, no. 3, pp. 927-935, 2010.

[91] W. Tarumi, S. Tsukamoto, Y. Okutsu et al., "Androstenedione induces abnormalities in morphology and function of developing oocytes, which impairs oocyte meiotic competence," Fertility and Sterility, vol. 97, no. 2, pp. 469-476, 2012.

[92] S. Romero and J. Smitz, "Exposing cultured mouse ovarian follicles under increased gonadotropin tonus to aromatizable androgens influences the steroid balance and reduces oocyte meiotic capacity," Endocrine, vol. 38, no. 2, pp. 243-253, 2010. 


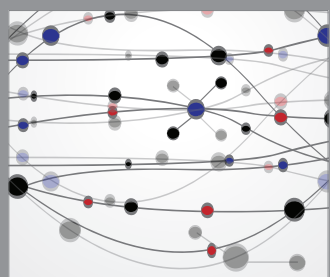

The Scientific World Journal
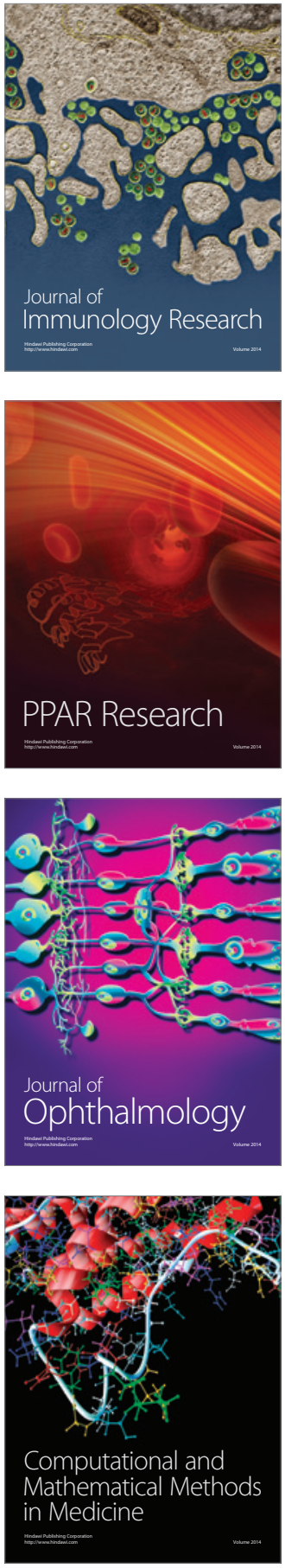

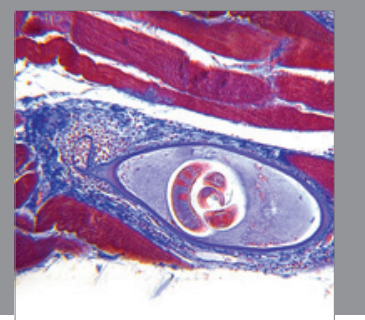

Gastroenterology

Research and Practice
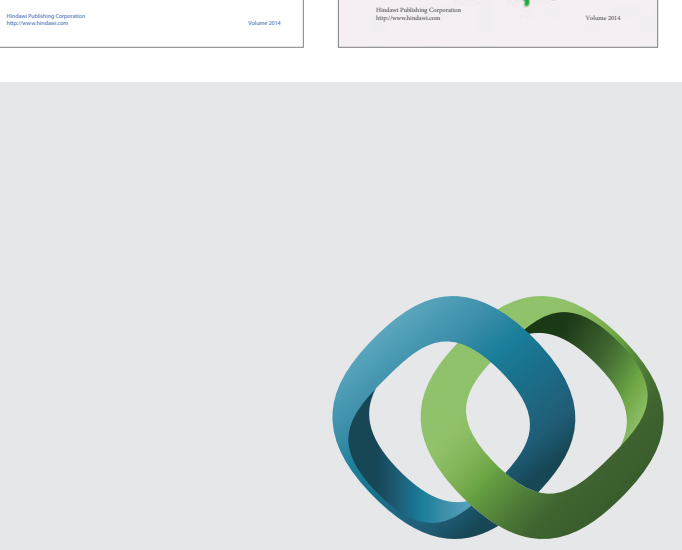

\section{Hindawi}

Submit your manuscripts at

http://www.hindawi.com
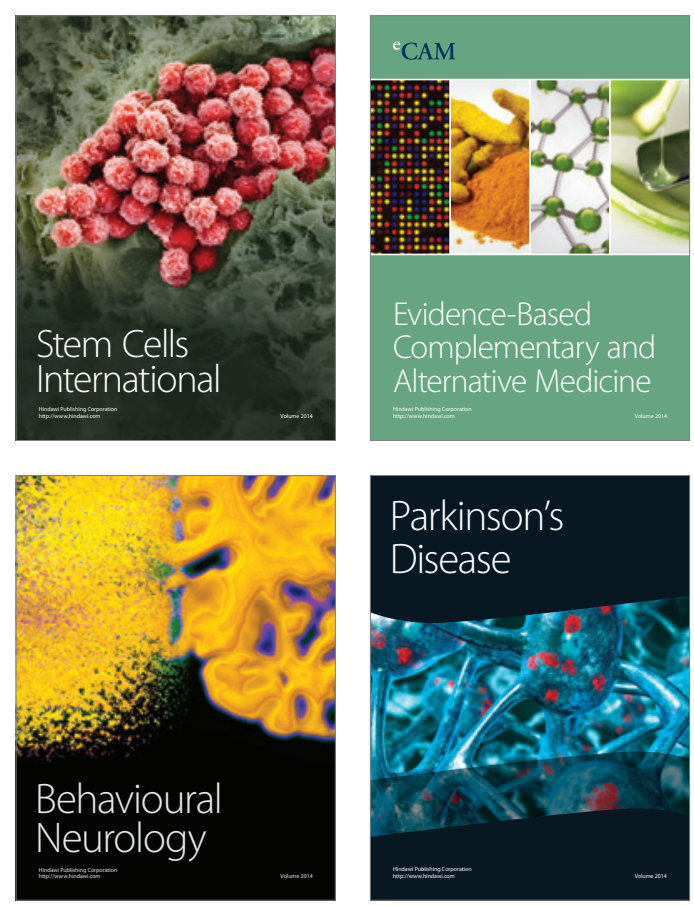

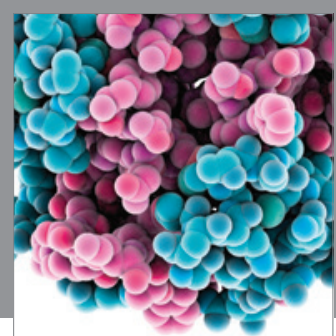

Journal of
Diabetes Research

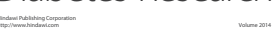

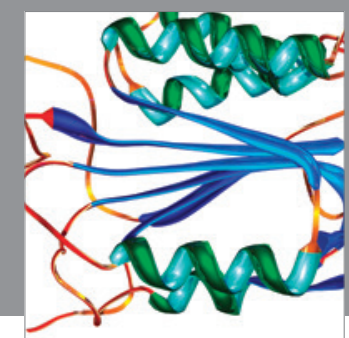

Disease Markers
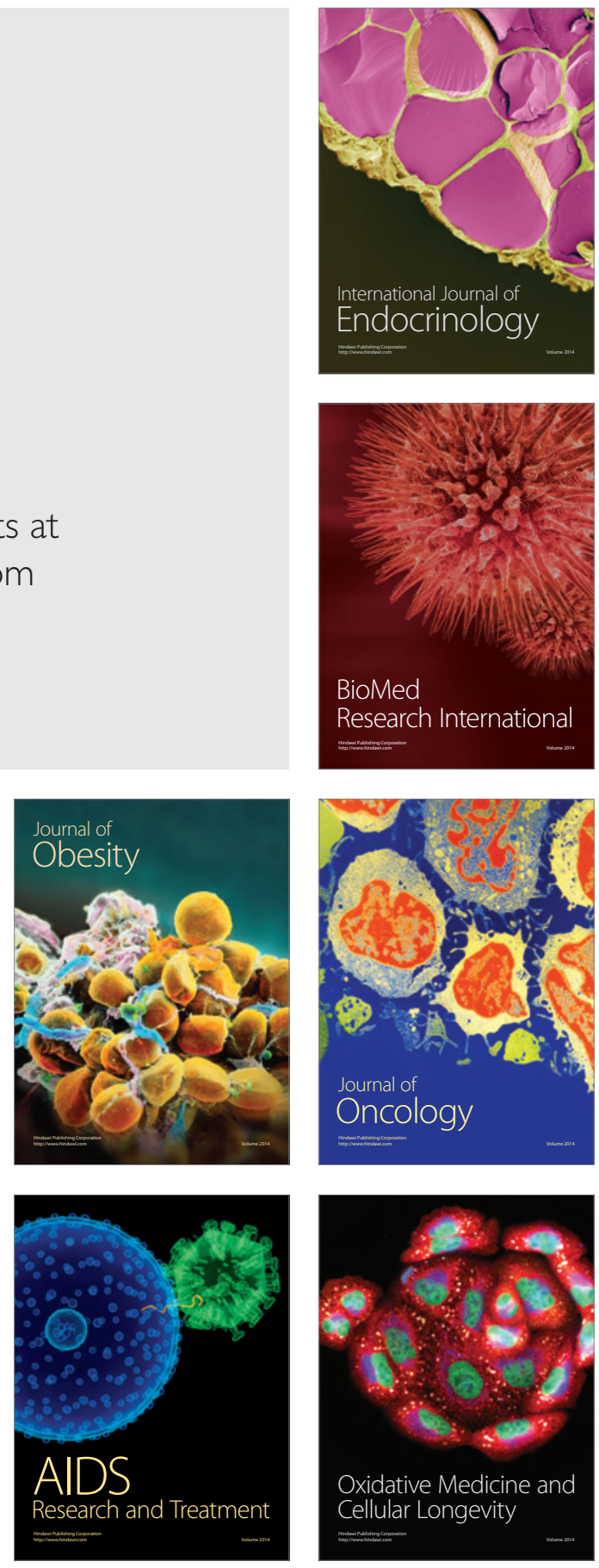